\title{
Literature Review:
}

\section{Risk Factors Associated With Renal Involvement in Childhood Henoch-schonlein Purpura}

Maryam Abdollahi $^{1}$ (D), Vadood Javadi ${ }^{{ }^{*}}$ (D), Reza Shiari ${ }^{1}$ (D), Khosro Rahmani ${ }^{1}$ (D) Mehrnoush Hassas Yeganeh $^{1}$ (D)

1. Department of Pediatric Rheumatology, Faculty of Medicine, Shahid Beheshti University of Medical Sciences, Tehran, Iran.

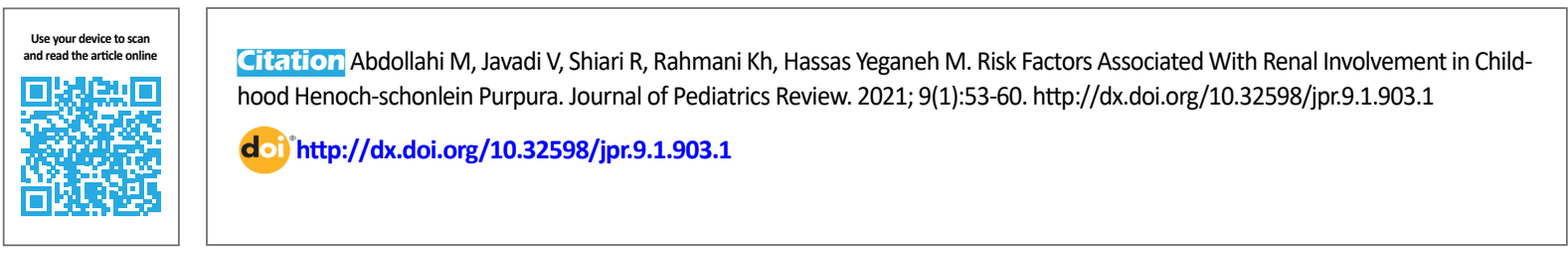

(c) (i) $($ )

Article info:

Received: 31 May 2020

First Revision: 10 Jun 2020

Accepted: 28 Sep 2020

Published: 01 Jan 2021
Keywords:

Henoch-schonlein purpura, Risk factor, Renal involvement, IgA vasculitis, Children

\section{A B S TR A C T}

Context: Henoch-Schonlein Purpura (HSP) is a significant cause of chronic renal disease in children. This review determines some risk factors associated with renal involvement in childhood HSP.

Evidence Acquisition: Electronic databases, including Google Scholar, PubMed, and Scopus were searched using the following keywords: "Children", "Henoch-Schonlein", "Risk factor", "Renal involvement", and "IgA vasculitis". This review was designed to identify the relevant electronic studies published in the English language from December 1998 to August 2018.

Results: This review revealed that clinically older age at presentation, persistent rash, atypical rash, rash on unusual location, and gastrointestinal bleeding were significant risk factors for renal involvement. In contrast, joint involvement was not associated with renal involvement. Among biochemical markers, high red blood cell distribution width is a risk marker of renal involvement in HSP. In contrast, peripheral blood immunoglobulin A, antinuclear antibody, anti-streptolysin $\mathrm{O}$ titer, erythrocyte sedimentation rate, and C-reactive protein were not associated with renal involvement. In several studies, leukocytosis, thrombocytosis, or thrombocytopenia have been mentioned as predictors for renal involvement. Still, other studies showed the white blood cell count or platelet count are not risk factors. The effect of corticosteroids as a predictive factor of renal involvement in HSP is challenging and controversial. Furthermore, their impact was dosedependent.

Conclusions: Demographic factors, clinical features, and some abnormal laboratory findings are significant predictive factors for renal involvement in HSP. 


\section{Context}

mmunoglobulin A vasculitis (IgA vasculitis), previously named Henoch-Schönlein Purpura (HSP), is a leukocytoclastic vasculitis with the deposition of IgA immune complexes in small vessels. It mainly affects capillaries, venules, or arterioles $(1,2)$. According to the European League Against Rheumatism, the Pediatric Rheumatology International Trials Organization, and the Pediatric Rheumatology European Society (EULAR/PRINTO/PRES) criteria, HSP should be diagnosed based on the presence of petechia or purpura (mandatory) with lower limb predominance, without coagulopathy or thrombocytopenia plus at least one of the following criteria: Gastrointestinal (GI) involvement, histopathology (IgA deposition), arthritis or arthralgia, or renal involvement (3).

Renal involvement is the most serious long-term complication of HSP. Based on EULAR/PRINTO/PRES criteria, HSP nephritis is defined as proteinuria: $>0.3 \mathrm{~g} / 24 \mathrm{~h}$, or $\geq$ $2+$ on dipstick and hematuria: red cell casts; urine sediment showing $>5$ red cells per high-power field or red cell casts (3). Additional symptoms include fever, scrotal involvement in boys, and rarely pulmonary, neurologic, or cardiac manifestations. It has a male predominance male-to-female ratio of $1.5: 1$ and typically affects children aged 3 to 15 years (4). To date, the HSP etiology has remained unknown, but a possible link between genetic predisposition and environmental factors such as infectious agents, insect bites, vaccines, drugs, or food allergens are considered for the pathogenesis of HSP (59). In a systematic review, renal involvement occurred in $34 \%$ of children. If the kidney gets involved, it happens early-in 4 weeks in $85 \%$ and 6 months in nearly all children (10).

Gastrointestinal symptoms occur in approximately one-half of children with Ig AV (HSP) and range from mild (nausea, vomiting, abdominal pain) to more significant complications (gastrointestinal bleeding, intussusception, and bowel perforation). The guaiac-positive stool in complicated patients is typical, but massive gastrointestinal bleeding is rare (11).

To date, HSP treatment has remained primarily supportive with the maintenance of adequate hydration, nutrition, and electrolyte balance. Still, corticosteroid treatment is commonly used in the acute phase of HSP, particularly for renal and GI involvement. Cyclophosphamide, azathioprine, cyclosporine, and plasmapheresis have been used in patients with different results (12-19). Although HSP is usually a self-limiting disease with a duration of about 4 weeks, it may have a relapsing-remitting course, and rarely, when complicated, it can be fatal (20).

The risk factors associated with renal involvement in HSP are not well known. However, epidemiologic and clinical features and some abnormal laboratory findings have been suggested to have a predictive role. In this narrative review, we assessed the quality of available evidence regarding risk factors that may predict renal involvement in childhood HSP and present a summary of our results.

\section{Evidence Acquisition}

Electronic databases, including Google Scholar, PubMed, and Scopus were searched using the following keywords: "Children", "Henoch-Schonlein purpura", "Risk factors", "Renal involvement", "Gastrointestinal involvement", and "IgA vasculitis". This review was designed to identify the relevant electronic studies published from December 1998 to August 2018. Among potentially relevant records, a total of 19 articles were selected. All papers included in this narrative review were in the English language.

\section{Results}

Nineteen articles were about risk factors of renal involvement in HSP. Table 1 presents the data extracted from each article by authors, year of publication, and study place. In these articles, we evaluated the risk factors of renal involvement in HSP. These risk factors are separately discussed below.

\section{Age}

There have been reports of different opinions about whether age can serve as the risk factor of renal involvement or not. There are research studies that consider age $\geq 6$ years, $\geq 8$ years, and $\geq 10$ years as the independent clinical risk factor of HSP renal involvement. This review suggests that the older age at onset was one of the significant risk factors of renal involvement in $\operatorname{HSP}(21-25,27)$

\section{Gender}

There have been some different reports about the effect of gender on renal involvement in HSP. Most studies agreed that gender was not a risk factor for renal involvement. In contrast, Elmas AT et al. reported a male preference, and Kilic BD et al. reported a female preference in sex ratio $(21,24,28-35)$. 
Table 1. Assessment of risk factors of renal involvement in HSP

\begin{tabular}{|c|c|c|c|c|c|}
\hline Authors & $\begin{array}{c}\text { Year of } \\
\text { Publication }\end{array}$ & $\begin{array}{l}\text { Place } \\
\text { of } \\
\text { Study }\end{array}$ & $\begin{array}{l}\text { Population } \\
\text { Data }\end{array}$ & Duration of Follow-up & Risk Factors \\
\hline Ma et al. (21) & 2017 & China & $\begin{array}{l}\text { HSP: } 250 \\
\text { HSPN: } 103\end{array}$ & One year & $\begin{array}{l}\text { Age, rash duration, GI involvement, WBC, } \\
\text { PLT, gender, joint involvement, ESR, CRP }\end{array}$ \\
\hline Youying et al. (22) & 2014 & China & $\begin{array}{l}\text { HSP: } 535 \\
\text { HSPN: } 267\end{array}$ & Six months & $\begin{array}{l}\text { Age, site of rash, GI involvement, joint in- } \\
\text { volvement, WBC, PLT, ESR, Ig A }\end{array}$ \\
\hline Reni et al. (23) & 2014 & $\begin{array}{l}\text { Indone- } \\
\text { sia }\end{array}$ & $\begin{array}{l}\text { HSP: } 128 \\
\text { HSPN: } 28\end{array}$ & Retrospective study & Age \\
\hline Yong-Li et al. (24) & 2015 & China & $\begin{array}{l}\text { HSP: } 141 \\
\text { HSPN: } 45\end{array}$ & Retrospective study & $\begin{array}{l}\text { Age, obesity, duration of rash, gender, joint } \\
\text { involvement, GI involvement, ASO, ANA, } \\
\text { ESR, CRP, PLT }\end{array}$ \\
\hline Shin et al. (25) & 2006 & Korea & $\begin{array}{l}\text { HSP: } 206 \\
\text { HSPN: } 78\end{array}$ & Retrospective study & $\begin{array}{l}\text { Age, gender, GI involvement, persistent } \\
\text { purpura, WBC, PLT, CRP, IgA }\end{array}$ \\
\hline Sano et al. (26) & 2002 & Japan & $\begin{array}{l}\text { HSP: } 134 \\
\text { HSPN: } 65\end{array}$ & Retrospective study & $\begin{array}{l}\text { Age, GI involvement, joint involvement, } \\
\text { persistent purpura, steroid use }\end{array}$ \\
\hline Wang et al. (27) & 2018 & China & $\begin{array}{l}\text { HSP: } 2731 \\
\text { HSPN: } 844\end{array}$ & Retrospective study & Age, CNS involvement \\
\hline Wang et al. (28) & 2016 & China & $\begin{array}{l}\text { HSP: } 131 \\
\text { HSPN: } 37\end{array}$ & Three years & $\begin{array}{l}\text { GI involvement, scrotal involvement, age, } \\
\text { gender, CRP, IgA }\end{array}$ \\
\hline Chang et al. (29) & 2005 & China & $\begin{array}{l}\text { HSP: } 261 \\
\text { HSPN: } 53\end{array}$ & Retrospective study & $\begin{array}{l}\text { Gl involvement, joint involvement, CNS in- } \\
\text { volvement, gender }\end{array}$ \\
\hline Rigant et al. (30) & 2005 & Italy & $\begin{array}{l}\text { HSP: } 94 \\
\text { HSPN: } 17\end{array}$ & Two years & $\begin{array}{l}\text { GI involvement, gender, persistent rash, } \\
\text { site of rash, WBC, ESR, CRP, IgA }\end{array}$ \\
\hline Xu et al. (31) & 2017 & China & $\begin{array}{l}\text { HSP: } 669 \\
\text { HSPN: } 256\end{array}$ & Retrospective study & $\begin{array}{l}\text { Age, gender, joint involvement, Gl involve- } \\
\text { ment, WBC, ESR, CRP, RDW, PLT }\end{array}$ \\
\hline Kaku et al. (32) & 1998 & Japan & $\begin{array}{l}\text { HSP: } 194 \\
\text { HSPN: } 65\end{array}$ & Two years & $\begin{array}{l}\text { Age, persistent purpura, gender, GI involve- } \\
\text { ment, joint involvement, steroid use }\end{array}$ \\
\hline Buscatti et al. (33) & 2018 & Brazil & $\begin{array}{l}\text { HSP: } 296 \\
\text { HSPN: } 139\end{array}$ & 15 years & $\begin{array}{l}\text { Gender, GI involvement, joint involvement, } \\
\text { CNS involvement, steroid use }\end{array}$ \\
\hline Elmas et al. (34) & 2016 & Turkey & $\begin{array}{l}\text { HSP: } 107 \\
\text { HSPN: } 28\end{array}$ & Six months & $\begin{array}{l}\text { Gender, scrotal involvement, joint involve- } \\
\text { ment, PLT, WBC, ESR, CRP, IgA }\end{array}$ \\
\hline Anil et al. (35) & 2019 & Turkey & $\begin{array}{l}\text { HSP: } 430 \\
\text { HSPN: } 192\end{array}$ & One year & $\begin{array}{l}\text { Age, gender, CNS involvement, GI involve- } \\
\text { ment, joint involvement, steroid use, WBC, } \\
\text { ESR, CRP }\end{array}$ \\
\hline Jauhola et al. (47) & 2010 & Finland & $\begin{array}{l}\text { HSP: } 223 \\
\text { HSPN: } 102\end{array}$ & Six months & $\begin{array}{l}\text { Age, GI involvement, ,gender, joint involve- } \\
\text { ment, scrotal involvement, ESR ,CRP, IgA }\end{array}$ \\
\hline $\begin{array}{l}\text { Limpongsanurak et } \\
\text { al. (48) }\end{array}$ & 2011 & Bangkok & $\begin{array}{l}\text { HSP: } 167 \\
\text { HSPN: } 11\end{array}$ & One year & $\begin{array}{l}\text { GI involvement, joint involvement, ASO, } \\
\text { corticosteroid use }\end{array}$ \\
\hline $\begin{array}{l}\text { Beltinge \& Belde } \\
\text { (49) }\end{array}$ & 2018 & Turkey & $\begin{array}{l}\text { HSP: } 186 \\
\text { HSPN: } 28\end{array}$ & 34 month & $\begin{array}{l}\text { Age, gender, GI involvement, skin location, } \\
\text { scrotal involvement, ASO, CRP, IgA }\end{array}$ \\
\hline Parvaneh et al. (57) & 2015 & Iran & $\begin{array}{l}\text { HSP: } 69 \\
\text { HSPN: } 6\end{array}$ & Ten years & Steroid use \\
\hline
\end{tabular}

Journal of Pediatrics Review

GI: Gastrointestinal; WBC: White Blood Cell; PLT: PLatelet; ESR: Erythrocyte Sedimentation Rate; CRP: C-Reactive Protein; Ig A: Immunoglobulin A; ASO: Anti-Streptolysin O; ANA: Anti-Nuclear Antibody; HSP: Henoch-Schonlein Purpura; HSPN: HSP Nephritis; RDW: Red Blood Cell Distribution Width; CNS: Central Nervous System.

Skin

The presence of palpable purpura is characteristic. This rash is most prominent on the dependent or pressurebearing surfaces, especially the lower extremities and buttocks, but it may occur in other areas (3). There have been several distinct skin rash issues, such as persistent rash, location of the rash, and atypical rash.

In two-thirds of children, HSP runs its entire course within 4 weeks after onset, but in others, purpura persists for one month or more, which is defined as persistent purpu- ra. We found that persistent purpura was associated with HSP Nephritis (HSPN) $(21,24-26,30,32,33)$.

Clinically, purpura on the lower limbs occurs in all patients with HSP, but a small percentage also have purpura on the face, neck, or upper limbs, and this was a significant risk factor for nephritis. So, HSP lesion location might be predictive of renal involvement and might be critical for risk stratification and treatment planning $(22,36)$.

Skin rash is the most common first manifestation of HSP, followed by gastrointestinal and joint symptoms. But some 
HSP patients exhibit skin lesions after 24 hours of presentation, defined as atypical cases, in which $\mathrm{Gl}$ and joint involvements appear before the skin lesions. In this review, we found that the atypical presentation of skin rash can increase the risk of developing renal involvement (35).

\section{GI involvement}

Abdominal pain, nausea, vomiting, or bleeding occurs in $51-74 \%$ of patients $(11,37-41)$, and $42 \%$ have severe abdominal pain (42). In 12-19\% of cases, abdominal pain was the presenting symptom $(38,39)$. The pain is characteristically colicky. It worsens after meals (11). The abdomen may have tenderness or resemble an acute abdomen, leading to unnecessary surgery. GI bleeding occurs in $18-52 \%$ of patients with $\operatorname{HSP}(11,37,39,40$, 42). Bleeding is usually mild but may occasionally become severe enough to require endoscopic or surgical therapy (43-45). Among the mentioned complication, digestive tract hemorrhage is a high-risk factor for renal involvement $(21,22,26,28,29,32,33,35)$.

\section{Joint involvement}

The joint manifestations included arthritis and arthralgia. The incidence of joint involvement in HSP patients may be as high as $78 \%$ (3). Joint involvement is the second most common feature after skin manifestations $(35,46)$. Based on the studies in our review, in contrast to GI involvement, joint involvement is not a risk factor for renal involvement in HSP patients $(21,22,24,26,31,33,34,47,48)$.

\section{Laboratory markers}

Analysis of laboratory indexes suggests that there were no differences in peripheral blood Immunoglobulin $A$ (IgA), Anti-Nuclear Antibody (ANA), Anti-Streptolysin O (ASO) titer, Erythrocyte Sedimentation Rate (ESR), and C-Reactive Protein (CRP) between two groups of HSP patients with and without renal involvement. However, different studies have been reported about the role of White Blood Cells (WBCs) and platelet in increasing the risk of renal involvement. Some studies revealed that leukocytosis, thrombocytosis, or thrombocytopenia are predictors for renal involvement; in contrast, others reported that WBC and platelet are not risk factors (21, $22,24-26,28,31,33-35,47,49)$.

Red blood cell Distribution Width (RDW) is routinely reported as a parameter of Complete Blood Count (CBC) that reflects the variability in the size of the erythrocytes in the blood. Also, RDW has been known as an inflammatory marker in various forms of inflammatory diseases (50-52). In this review, we found that high RDW is a risk marker of renal involvement in HSP (31).

\section{Treatment with Corticosteroid}

As noted above, HSP treatment is mainly supportive, but in some cases, corticosteroids are prescribed in severe disease manifestations, for example, serious GI involvement and hemorrhage, pulmonary hemorrhage, and severe orchitis (53). There is considerable controversy in the published literature regarding the effect of corticosteroids as a predictive factor of renal involvement in HSP. Kaku et al. (32) and Mollica et al. (54) reported that corticosteroids diminished the risk of renal involvement. However, Ronkainen et al. (55) revealed that early prednisone therapy did not prevent the development of renal involvement. In contrast, Huber et al. (56) found no effect of prednisone in reducing renal involvement during 1-year follow-up. Murat Anil et al. (35) demonstrated that early use of corticosteroid (1-2 $\mathrm{mg} / \mathrm{kg} / \mathrm{d}$ ) was associated with greater renal involvement; in contrast, Parvaneh et al. (57) showed that use of high dose corticosteroid (pulse methylprednisolone) would reduce renal complication. Our main study limitation is the unavailability of some information in each study, such as the periods for urinary abnormalities observed after the HSP diagnosis, time for the observed outcome, the dose of corticosteroid, and duration of their use. Further studies are needed to reveal the relationship between corticosteroid usage and renal involvement.

\section{Conclusion}

HSP nephritis is seen as the main reason for End-Stage Renal Disease (ESRD) among pediatric patients. Overall, HSP accounts for about $1 \%$ of patients with ESRD from all causes. Therefore, early diagnosis of renal involvement plays an essential role in avoiding or delaying the occurrence of ESRD. Although epidemiological factors and clinical manifestation, and some abnormal laboratory findings, are considered to have a predictive effect, the full set of risk factors associated with renal involvement remains unclear. Therefore, further studies are needed to document a risk evaluation model for renal involvement in HSP.

\section{Ethical Considerations}

\section{Compliance with ethical guidelines}

There were no ethical considerations to be considered in this research. 
Funding

This research did not receive any grant from funding agencies in the public, commercial, or non-profit sectors.

\section{Authors' contributions}

All authors equally contributed to preparing this article.

\section{Conflicts of interest}

The authors declared no conflict of interest.

\section{References}

1. Ueda H, Miyazaki Y, Tsuboi N, Hirano K, Yokote S, Kobayashi $E$, et al. Clinical and pathological characteristics of elderly Japanese patients with IgA vasculitis with nephritis: A case series. Internal Medicine Journal. 2019; 58(1):31-8. [DOI:10.2169/internalmedicine.1379-18] [PMID] [PMCID]

2. Jennette JC, Falk RJ, Bacon PA, Basu N, Cid MC, Ferrario F, et al. 2012 revised international Chapel Hill consensus conference nomenclature of vasculitides. Arthritis \& Rheumatism. 2013; 65(1):1-11. [DOI:10.1002/art.37715] [PMID]

3. Ozen S, Pistorio A, lusan SM, Bakkaloglu A, Herlin T, Brik R, et al. EULAR/PRINTO/PRES criteria for Henoch-Schönlein purpura, childhood polyarteritis nodosa, childhood Wegener granulomatosis and childhood Takayasu arteritis: Ankara 2008. Part II: Final classification criteria. Annals of the Rheumatic Diseases. 2010; 69(5):798-806. [DOI:10.1136/ ard.2009.116657] [PMID]

4. Rostoker G. Schönlein-Henoch purpura in children and adults: diagnosis, pathophysiology and management. Biodrugs. 2001; 15(2):99-138. [DOI:10.2165/00063030200115020-00004] [PMID]

5. Rigante D, Castellazzi L, Bosco A, Esposito S. Is there a crossroad between infections, genetics, and Henoch-Schönlein purpura? Autoimmunity Reviews. 2013; 12(10):1016-21. [DOI:10.1016/j.autrev.2013.04.003] [PMID]

6. Olson JC, Kelly KJ, Pan CG, Wortmann DW. Pulmonary disease with hemorrhage in Henoch-Schönlein purpura. Pediatrics. 1992; 89(6 Pt 2): 1177-81. https://pediatrics.aappublications.org/content/89/6/1177.short

7. Dedeoglu F, Kim S. Henoch-Schönlein purpura (immunoglobulin A vasculitis): Management. Up-to-Date. 2015:1-7 https://www.uptodate.com/contents/iga-vasculitis-henoch-schonlein-purpura-management

8. Wakai K, Kawamura T, Endoh M, Kojima M, Tomino Y, Tamakoshi A, et al. A scoring system to predict renal outcomein IgA nephropathy: From a nationwide prospective study.
Nephrology Dialysis Transplantation. 2006; 21:2800-8. [DOI:10.1093/ndt/gfl342] [PMID]

9. Shiari R, Mirjavadi SA, Javadi V, Yegane M. Leukocytoclastic vasculitis with thyphoid fever. Annals of the Rheumatic Diseases. 2012; 1(4):240-2. [DOI:10.5455/apr.111720120603]

10. Narchi H. Risk of long term renal impairment and duration of follow up recommended for Henoch-Schonlein purpura with normal or minimal urinary findings: A systematic review. Archives of Disease in Childhood. 2005; 90(9):916-20. [DOI:10.1136/adc.2005.074641] [PMID] [PMCID]

11. Chang WL, Yang YH, Lin YT, Chiang BL. Gastrointestinal manifestations in Henoch-Schönlein purpura: A review of 261 patients. Acta Paediatrica. 2004; 93:1427. [DOI:10.1111/j.1651-2227.2004.tb02623.x] [PMID]

12. Niaudet $P$, Habib R. Methylprednisolone pulse therapy in the treatment of severe forms of Schonlein-Henoch purpura nephritis. Journal of Pediatric Nephrology. 1998; 12(3):238-43. [DOI:10.1007/s004670050446] [PMID]

13. Foster BJ, Bernard C, Drummond KN, Sharma AK. Effective therapy for severe Henoch-Schonlein purpura nephritis with prednisone and azathioprine: A clinical and histophatologic study. Journal of Pediatrics. 2000; 136:370-5. [DOI:10.1067/mpd.2000.103448] [PMID]

14. Bergstein J, Leiser J, Andreoli SP. Response of crescentic Henoch-Schoenlein purpura nephritis to corticosteroid and azathioprine therapy. Clinical Nephrology. 1998; 49(1):9-14. [PMID]

15. Flynn JT, Smoyer WE, Bunchman TE, Kershaw DB, Sedman $A B$. Treatment of Henoch-Schonlein purpura glomerulonephritis in children with high-dose corticosteroids plus oral cyclophosphamide. American Journal of Nephrology. 2001; 21(2):128-33. [DOI:10.1159/000046235] [PMID]

16. Ronkainen J, Autio-Harmainen H, Nuutinen M. Cyclosporin A for the treatment of severe Henoch-Schonlein glomerulonephritis. Pediatric Nephrology. 2003; 18(11):1138-42. [DOI:10.1007/s00467-003-1245-7] [PMID]

17. lijima K, Ito-Kariya S, Nakamura H, Yoshikawa N. Multiple combined therapy for severe Henoch-Schönlein nephritis in children. Pediatric Nephrology. 1998; 12(3):244-8. [DOI:10.1007/s004670050447] [PMID]

18. Shenoy M, Ognjanovic MV, Coulthard MG. Treating severe Henoch-Schönlein and IgA nephritis with plasmapheresis alone. Pediatric Nephrology. 2007; 22(8):1167. [DOI:10.1007/s00467-007-0498-y] [PMID]

19. Counsell C, Fraser H. Identifying relevant studies for systematic reviews. BMJ: British Medical Journal. 1995; 310(6972):126.[DOI:10.1136/bmj.309.6964.1286] [PMID] [PMCID]

20. Paller AS, Kelly K, Sethi R. Pulmonary hemorrhage: An often fatal complication of Henoch-Schoenlein purpura. Pediatric Dermatology. 1997; 14(4): 299-302. [DOI:10.1111/j.1525-1470.1997.tb00963.x] [PMID] 
21. Ma DQ, Li Y, Han ZG, Zheng M, Xu N, Fan XJ. Analysis on kidney injury-related clinical risk factors and evaluation on the therapeutic effects of hemoperfusion in children with Henoch-Schonlein purpura. European Review for Medical and Pharmacological Sciences. 2017; 21(17):3894-9. http://www.europeanreview.org/wp/wp-content/ uploads/3894-3899-Risk-factors-and-effects-of-hemoperfusion-in-HSP-children.pdf

22. Mao $Y$, Yin L, Huang $H$, Zhou Z, Chen T, Zhou W. HenochSchönlein purpura in 535 Chinese children: Clinical features and risk factors for renal involvement. Journal of International Medical Research. 2014; 42(4):1043-9. [DOI:10.1177/0300060514530879] [PMID]

23. Reni G, Masayu AL, Gartika Si, Budi S. Age of onset as a risk factor of renal involvement in Henoch-Schönlein purpura. Asia Pacific Allergy. 2014; 4(1):42-47. [DOI:10.5415/apallergy.2014.4.1.42] [PMID] [PMCID]

24. Zhao YL, Liu ZJ, Bai XM, Wang YC, Li GH, Yan XY. Obesity increases the risk of renal involvement in children with $\mathrm{He}$ noch-Schönlein purpura. European Journal of Pediatrics. 2015; 174(10):1357-63. [DOI:10.1007/s00431-015-2547-z] [PMID]

25. Shin JI, Park JM, Shin YH, Hwang DH, Kim JH, Lee JS. Predictive factors for nephritis, relapse, and significant proteinuria in childhood Henoch-Schönlein purpura. Scandinavian Journal of Rheumatology. 2006; 35(1):56-60. [DOI:10.1080/03009740510026841] [PMID]

26. Sano H, Izumida M, Shimizu H, Ogawa Y. Risk factors of renal involvement and significant proteinuria in HenochSchönlein purpura. European Journal of Pediatrics. 2002; 161(4):196-201.[DOI:10.1007/s00431-002-0922-z] [PMID]

27. Wang K, Sun $X$, Cao Y, Dai L, Sun F, Yu P, et al. Risk factors for renal involvement and severe kidney disease in 2731 Chinese children with Henoch-Schönlein purpura: A retrospective study. Medicine. 2018; 97(38):e12520. [DOI:10.1097/MD.0000000000012520] [PMID] [PMCID]

28. Wang X, Zhu Y, Gao L, Wei S, Zhen Y, Ma Q. Henoch-Schönlein purpura with joint involvement: Analysis of 71 cases. Pediatric Rheumatology. 2016; 14(1):1-8. [DOI:10.1186/ s12969-016-0080-x] [PMID] [PMCID]

29. Chang WL, Yang YH, Wang LC, Lin YT, Chiang BL. Renal manifestations in Henoch-Schönlein purpura: A 10-year clinical study. Pediatric Nephrology. 2005; 20(9):1269-72. [DOI:10.1007/s00467-005-1903-z] [PMID]

30. Rigante D, Candelli M, Federico G, Bartolozzi F, Porri MG, Stabile A. Predictive factors of renal involvement or relapsing disease in children with Henoch-Schönlein purpura. Rheumatology International. 2005; 25(1):45-8. [DOI:10.1007/s00296-004-0452-2] [PMID]

31. Xu H, Li W, Mao JH, Pan YX. Association between red blood cell distribution width and Henoch-Schonlein purpura nephritis. Medicine. 2017; 96(23). [DOI:10.1097/ MD.0000000000007091] [PMID] [PMCID]
32. Kaku Y, Nohara K, Honda S. Renal involvement in HenochSchönlein purpura: A multivariate analysis of prognostic factors. Kidney International. 1998; 53(6):1755-9. [DOI:10.1046/j.1523-1755.1998.00915.x] [PMID]

33. Buscatti IM, Casella BB, Aikawa NE, Watanabe A, Farhat SC Campos LM, et al. Henoch-Schönlein purpura nephritis: Initial risk factors and outcomes in a Latin American tertiary center. Clinical Rheumatology. 2018; 37(5):1319-24. [DOI:10.1007/s10067-017-3972-3] [PMID]

34. Elmas AT, Yilmaz T. Platelet counts in children with henoch schonlein purpura-relationship to renal involvement. Journal of Clinical Laboratory Analysis. 2016; 30(1):71-4. [DOI:10.1002/jcla.21817] [PMID] [PMCID]

35. Anil M, Aksu N, Kara OD, Bal A, Anil AB, Ün B. HenochSchönlein purpura in children from western Turkey: $A$ retrospective analysis of 430 cases. The Turkish Journal of Pediatrics. 2009; 51(5):429. http://www.turkishjournalpediatrics.org/uploads/pdf_TJP_686.pdf

36. John JS, Vedak P, Garza-Mayers AC, Hoang MP, Nigwekar SU, Kroshinsky D. Location of skin lesions in Henoch-Schönlein purpura and its association with significant renal involvement. Journal of the American Academy of Dermatology. 2018; 78(1):115-20. [DOI:10.1016/j.jaad.2017.04.1122] [PMID]

37. Calvino MC, Llorca J, García-Porrúa C, Fernandez-Iglesias JL, Rodriguez-Ledo P, Gonzalez-Gay MA. Henoch-Schönlein purpura in children from northwestern Spain: A 20year epidemiologic and clinical study. Medicine. 2001; 80(5):279-90. [DOI:10.1097/00005792-200109000-00001] [PMID]

38. Saulsbury FT. Henoch-Schönlein purpura in children. Report of 100 patients and review of the literature. Medicine. 1999; 78(6):395-409. [DOI:10.1097/00005792199911000-00005] [PMID]

39. Trapani S, Micheli A, Grisolia F, Resti M, Chiappini E, Falcini $\mathrm{F}$, et al. Henoch Schonlein purpura in childhood: Epidemiological and clinical analysis of 150 cases over a 5-year period and review of literature. In Seminars in Arthritis and Rheumatism. 2005; 35(3):143-53. [DOI:10.1016/j.semarthrit.2005.08.007] [PMID]

40. Lindenauer S, Tank E. Surgical aspects of Henoch- Schonlein's purpura. Surgery. 1966; 59(6):982-987. https://www. surgjournal.com/article/0039-6060(66)90298-4/fulltext

41. Katz S, Borst M, Seekri I, Grosfeld JL. Surgical evaluation of Henoch-Schönlein purpura experience with 110 children. Archives of Surgery. 1991; 126(7):849-54. [DOI:10.1001/ archsurg.1991.01410310059008] [PMID]

42. Schwab J, Benya E, Lin R, Majd K. Contrast enema in children with Henoch-Schönlein purpura. Journal of Pediatric Surgery. 2005; 40(8):1221-3. [DOI:10.1016/j.jpedsurg.2005.05.001] [PMID]

43. Ebina K, Kato S, Abukawa D, Nakagawa H. Endoscopic hemostasis of bleeding duodenal ulcer in a child with He- 
noch-Schönlein purpura. The Journal of Pediatrics. 1997; 131(6):934-6. [DOI:10.1016/S0022-3476(97)70049-0]

44. Lippl F, Huber W, Werner M, Nekarda H, Berger H, Weigert $\mathrm{N}$. Life-threatening gastrointestinal bleeding due to a jejunal lesion of Henoch-Schönlein purpura. Endoscopy. 2001; 33(09):811-3. [DOI:10.1055/s-2001-16529] [PMID]

45. Agha FP, Nostrant TT, Keren DF. Leucocytoclastic vasculitis (hypersensitivity angiitis) of the small bowel presenting with severe gastrointestinal hemorrhage. The American Journal of Gastroenterology. 1986; 81(3):195-8. https:// deepblue.lib.umich.edu/bitstream/handle/2027.42/7538 0/j.1572-0241.1986.tb01459.x.pdf; sequence=1

46. Saulsbury FT. Clinical update: Henoch-Schonlein purpura. The Lancet. 2007; 369(9566):976-8. [DOI:10.1016/S01406736(07)60474-7]

47. Jauhola $\mathrm{O}$, Ronkainen J, Koskimies $\mathrm{O}$, Ala-Houhala $\mathrm{M}$, Arikoski $\mathrm{P}$, Hölttä $\mathrm{T}$, et al. Renal manifestations of Henoch-Schönlein purpura in a 6-month prospective study of 223 children. Archives of Disease in Childhood. 2010; 95(11):877-82. [DOI:10.1136/adc.2009.182394] [PMID]

48. Limpongsanurak W, Kietkajornkul C, Singalavanija S. Predictive factor of severe renal involvement in children with Henoch-Schoenlein purpura. Medical Association of Thailand. 2011; 94:204-8. https://www.researchgate.net/profile/Srisupalak_Singalavanija/publication/51761561_

49. Beltinge D, Belde K. Determination of risk factors in children diagnosed with henoch-schönlein purpura. Archives of Rheumatology. 2018; 33(4):395-401. [DOI:10.5606/ ArchRheumatol.2018.6562] [PMID] [PMCID]

50. Kim CH, Park JT, Kim EJ, Han JH, Han JS, Choi JY, et al. An increase in red blood cell distribution width from baseline predicts mortality in patients with severe sepsis or septic shock. Critical Care. 2013; 17(6):R282. [DOI:10.1186/ cc13145] [PMID] [PMCID]

51. Song CS, Park DI, Yoon MY, Seok HS, Park JH, Kim HJ, et al. Association between red cell distribution width and disease activity in patients with inflammatory bowel disease. Digestive Diseases and Sciences. 2012; 57(4):1033-8. [DOI:10.1007/s10620-011-1978-2] [PMID]

52. Bozlu G, Taskinlar H, Unal S, Alakaya M, Nayci A, Kuyucu $\mathrm{N}$. Diagnostic value of red blood cell distribution width in pediatric acute appendicitis. Pediatrics International. 2016; 58(3):202-5. [DOI:10.1111/ped.12805] [PMID]

53. Petty R, Lindsley C, Laxer R. Textbook of pediatric rheumatology, $7^{\text {th }}$ edition. Elsevier. https://www.elsevier. com/books/textbook-of-pediatric-rheumatology/petty/978-0-323-24145-8

54. Mollica F, LiVolti S, Garozzo R, Russo G. Effectiveness of early prednisone treatment in preventing the development of nephropathy in anaphylactoid purpura. European Journal of Pediatrics. 1992; 151(2):140-4. [DOI:10.1007/ BF01958961] [PMID]
55. Ronkainen J, Koskimies O, Ala-Houhala M, Antikainen M, Merenmies J, Rajantie J, et al. Early prednisone therapy in Henoch-Schönlein purpura: A randomized, double-blind, placebo-controlled trial. The Journal of Pediatrics. 2006; 149(2):241-7. [DOI:10.1016/j.jpeds.2006.03.024] [PMID]

56. Huber AM, King J, McLaine P, Klassen T, Pothos M. A randomized, placebo-controlled trial of prednisone in early Henoch Schönlein Purpura [ISRCTN85109383]. BMC Medicine. 2004; 2(1):1-7. [DOI:10.1186/1741-7015-2-7] [PMID] [PMCID]

57. Parvaneh VJ, Shiari R, Rahmani K, Mehregan FF, Mahboubi L, Salehi S, et al. AB1013 pulse of methylprednisolone may reduce the risk of renal involvement in children with Henoch-Schonlein Purpura. BMJ Journal. 2015; 74(2):1-10. http://group.bmj.com/group/rights-licensing/permissions 
This Page Intentionally Left Blank 